\title{
The Impact of the COVID-19 Pandemic and Work From Home Policy on Poor Communities and Women in Rural Area
}

\author{
Lutfi Apreliana Megasari 1, (D), Siti Mas'udah 1,*, (D), and \\ Priyono Tri Febrianto 2, \\ ${ }^{1}$ Department of Sociology, Faculty of Social and Political Sciences, \\ Universitas Airlangga, 60115, Surabaya, East Java Province, Indonesia \\ 2 Department of Primary School Teacher Education, Faculty of Science Education, \\ Universitas Trunojoyo Madura, 69162, Bangkalan, East Java Province, Indonesia \\ * Corresponding Author: siti.masudah@fisip.unair.ac.id
}

\section{ARTICLE INFO}

\section{Publication Info: \\ Research Article}

How to cite:

Megasari, L. A., Mas'udah, S. E Febrianto, P. T. (2021). The Impact of the COVID-19

Pandemic and Work From Home Policy on Poor Communities and Women in Rural Area. Society, 9(2), 522-538.

DOI: $10.33019 /$ society.v9i2.285

Copyright () 2021. Owned by Author(s), published by Society

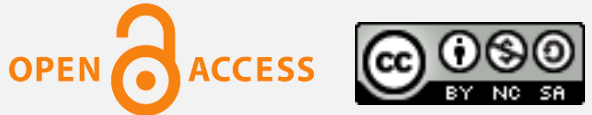

This is an open-access article.

License: Attribution-

NonCommercial-ShareAlike (CC BY-NC-SA)

\begin{abstract}
The COVID-19 outbreak has brought multiple profound effects on the economic sector worldwide. This study aims to determine the socio-economic impact caused by the COVID-19. Considering Indonesian lower-classes, this study used a quantitative method with a descriptive approach and collected 274 respondents. Data were obtained from questionnaire interviews with poor women in rural East Java. The data source was selected using a random sampling technique. Literature studies were carried out to collect data related to research. The results show that the pandemic in Indonesia has caused a tremendous impact on the socio-economic sector of society and women from the lower classes in rural areas. They suffer from huge losses ranging from reduced income to loss of work. This study also highlights the Work From Home (WFH) policy, which cannot be implemented on the lower classes because many of them are laid off, and some employees who continue to work are at risk of disease exposure. Likewise, the COVID-19 pandemic and Work From Home (WFH) policy evoke several problems for women. The household responsibility of women is proven to increase during the pandemic. The women who do WFH seem to be preoccupied in two roles, first, as a worker, second, as a housewife who assists the household. Specifically, it means women are required to do domestic and public work. Therefore, gender awareness is needed to minimize women's disadvantages in this case.
\end{abstract}


The Impact of the COVID-19 Pandemic and Work From Home Policy on Poor Communities and Women in Rural Area

Received: January 12, 2021;

Accepted: June 29, 2021;

Published: December 31, 2021;

Keywords: COVID-19 Pandemic; Lower Class; Poor;

Poverty; Social Economic Impact; Women

\section{Introduction}

The COVID-19 that outbreaks in almost all countries globally significantly impacts all factors. This pandemic which develops rapidly encourages countries to apply mitigation on economic fallout worldwide (Atkeson, 2020). Most countries perceive a severe economic impact. Globally, the economic activity has faltered due to this pandemic. Enforcement of locking the area to quarantine (lockdown) affects many people unable to work normally. Furthermore, the pandemic itself badly affects large-scale companies and the informal sector.

The virus has brought many disadvantages to the economic sector, including death and illness, loss of income, time, and medical costs (Fernandes, 2020; Hall et al., 2020; McKibbin \& Roshen, 2020). Various economic sectors were paralyzed, which caused many employees to be laid off from work. Currently, the high unemployment rate is a problem for many countries worldwide. In addition, the COVID-19 does lower not only the health system but also attacks other sectors. The rise of the mortality rate in developing countries reflects the country's deteriorated economic conditions.

Baker et al. (2020) explain that the COVID-19 pandemic triggered uncertainties such as temporarily closing traditional markets, acceleration of economic recovery, business survival, new business formation, and capital investment. The developed country such as the United States also overwhelms battling with COVID-19. The virus which originated from China has also paralyzed the country itself, affecting the local country's economic security. On the other hand, although logistical deliveries are still executed as part of economic activity, many companies have reduced the scale of production and are forced to relinquish employment. As a result, many workers are unemployed, especially hotel services and tourism workers.

The COVID-19 triggers fears of an economic crisis and recession in various developed countries because the economic advantage is no longer based on cheap oil, while fuel savings are unlikely (Nicola et al., 2020; Ozili \& Arun, 2020; Sułkowski, 2020). Economic transactions among countries are slowly getting worse each day. This pandemic situation shows that none of the countries in this world is superior. Prosperous countries with their giant economic system end up experiencing the same problem.

Alvarez et al. (2020) stated that many countries ignore the long-term economic consequences of lockdown and focus on medical treatment. This means that various countries override economic affairs. They assume that the risk of transmission of this virus will be significantly higher if the economic sector continues to be pursued. Therefore, strictly implementing lockdown seems to be the best option for countries across the globe. Another study also mentioned that the COVID-19 pandemic caused shocks that could cause output losses greater than efficient, especially the dominance of decreased supply (Guerrieri et al., 2020; Inoue \& Todo, 2020; Toda, 2020).

The mass closure of schools and workplaces impacts women's delimitation in the workforce and economic opportunities, especially financial challenges and uncertainties for women workers (Alon et al., 2020; Wenham et al., 2020; Fuchs-Schelnund, 2020). In the end, the termination of employment brings family financial shock. For health safety reasons, implementing new habit protocols leads to economic instability. The financial challenge experienced by society is the representation of the virus's destructive effects.

Copyright (C 2021. Owned by Author(s), published by Society. This is an open-access article under the CC-BY-NC-SA license. https://doi.org/10.33019/society.v9i2.285

523 
According to research conducted by Baldwin \& Mauro (2020), countries infected by COVID-19 are the G-7 countries plus China. The major obstacle lies in demand disruption due to aggregate macro-economic decline, consumer delays in purchasing, and the postponement of investment from companies. Industrialized countries experiencing the effects considering export-imports have fallen sharply amid COVID-19 disruptions. Moreover, giant companies that play a significant role as the economic pillars are inevitably vulnerable to the same effects. Additionally, the crisis also threatens disproportionately developing countries. The virus also particularly brings catastrophic impacts in lower-class society. Previous studies expose that this pandemic has caused travel restrictions and tickets cancellation, higher unemployment, and some people cannot work from home, including people without a degree (Coibion et al., 2020; Hevia \& Neumeyer, 2020; Tesso, 2020). These things are inherent in developing countries where the economy still relies on inadequate natural and human resources.

A study by Van Lancker \& Parolin (2020) explores that prolonged school closures associated with the COVID-19 pandemic are likely to impact society negatively and have major consequences for children in lower-income households further, it will exacerbate inequality. In poor communities, shutting schools and transforming the learning system into online methods is ineffective. Apart from the lack of facilities, poor children cannot access online learning systems due to low cost. This outbreak intensifies inequalities that occur in developing countries. Other studies also concluded that there were many losses caused by COVID-19, such as labor market disputes, changes in public consumption, non-monetary poverty, and education (Ahmed et al., 2020; Sumner et al., 2020).

Many people assume that lower-class society holds a significant issue in handling COVID19. The poor generally associate with unhealthy lifestyles to spread the virus rapidly. On the contrary, this virus contaminates the immune system due to high mobility, which the upperclass society commonly experiences. On the other side, poverty is seen as reducing compliance in the COVID-19 protocol (Wright et al., 2020). Poverty is also seen as a resistor for recovery efforts on tackling COVID-19 because the budget for the procurement of health facilities must be shared for social assistance for the poor.

Besides enforcing healthy habit procedures, Indonesia also faces the same situation, not imposing territorial lockdown and restrictions. The country applies new habit protocols, i.e., physical distancing, Work From Home, and self-quarantine. The protocols have been strictly implemented, considering that various economic sectors were paralyzed. On the other side, Indonesia progressively prepares for economic development, and the government assesses lockdown as unnecessary because it will only worsen the economic resilience. Previous studies mentioned that the Pakistani economy projected to decrease around 3.3\% since 2019 by the Asian Development Bank, while Nigeria had 24\% of the total population living below the national poverty line, so, from above, it can be identified that COVID-19 lockdowns are difficult for developing countries (Buheji et al., 2020; Loayza \& Pennings, 2020; Mamun \& Ullah, 2020).

The COVID-19 is likely to attack countries with inadequate health facilities (Anser et al., 2020). It is speculated that inadequate health facilities could impede the containment of the pandemic. Anser's findings are not entirely true because this disaster still traps developed countries with organized health facilities. China, Italy, the United States, Finland, and the UAE have developed massive COVID-19 exposure.

This virus could ultimately be a disaster because it causes death and delivers negative impacts. Fundamentally, natural disasters cause short-term and long-term economic effects (Cavallo et al., 2013). Like the COVID-19 outbreak, this circumstance will also leave short- and 
long-term economic impacts. Temporarily, almost all economic sectors will be badly damaged, while permanently, effects are likely to impact economic cooperation between countries significantly.

Numerous countries have been striving to contain COVID-19 promptly. After the disastrous pandemic, the efforts to regain economic stability are gradually implemented by controlling income and losses incurred, making the economic system more open, completing the financial system, and streamlining governance (Toya \& Skidmore, 2007). Many countries unexpectedly experienced an economic downturn, and in reality, entrepreneurs have been on the verge of bankruptcy. Thus, this affects the workers. Hotel companies and tourism service businesses went bankrupt. Therefore, it can be concluded that the economic recovery has not shown any improvements. Furthermore, pandemic disruption also attacks social and economic activities, which leads to implications for people's welfare and vulnerability (Adeagbo et al., 2016).

Following Kreimer et al. (2003), the study explored that disasters negatively affected the economy, namely the global economic slowdown, which affected trade transactions. The economic downturn caused by the disaster caused the inability to run economic transactions between individuals and on a global scale. The COVID-19 outbreak impacted sales activity in the trade sector because the economic slump caused diminishing money exchange. Moreover, it is also entangled in lower-class society.

Alternatively, a study conducted by Fothergill (2003) found that disaster management was easily executed on the poor communities. Aid providers the government easily recognize the lower class with the worst economy. Meanwhile, not all lower-classes are covered by government assistance. In some cases, people who originate from the middle class could be financially devastated might be less likely to get assistance because of the assumption of their social status background. In addition, the occurrence of disasters also reveals inequality in lowincome societies because they are powerless socially, politically, and economically (Motesharrei et al., 2014).

Research on COVID-19 has begun by various experts and academicians, especially those from medicine, science, and technology. This paper focuses on the lower-classes society affected by COVID-19. Many studies have been found concerning disaster and poverty in several other studies. This paper presents a portrait of poverty amid the COVID-19 outbreak because it has a multi-complex effect that cannot be linked to one aspect of poverty.

\section{Research Methodology}

The main goal of this study is to examine the impacts of the COVID-19 on lower-class communities and women in rural areas. This research used quantitative methods with descriptive data analysis. The data was gathered through structured interviews from 274 lowincome families living in East Java, Indonesia. The data source was obtained using the random sampling technique. Literature studies were carried out to collect data related to research.

In addition, interviews were conducted with families with tremendous damage due to the COVID-19 pandemic. The study focused on respondents who lost their jobs or were laid off to reveal low-income families' socio-economic conditions and the pandemic's impact on them dan women.

Data from in-depth interviews were classified and categorized according to the research objectives. Then, the data was analyzed, interpreted, and discussed with comparative studies relevant to the study. The data collected from respondents is then presented in table form. 


\section{Results and Discussion}

The COVID-19 pandemic brings multiple effects on the global population. Including Indonesia, the outbreak also has a significant influence in various sectors. This study found that COVID-19 influences the socio-economic conditions of the Indonesian population, especially the lower classes. The emergence of this pandemic transformed the economic aspect into the situation of various groups in Indonesia experienced a pretty severe impact. Due to this outbreak, some sectors have even been forced to close their income fields. This outbreak forced employers to close their businesses in the tourism and hospitality sector, causing many workers to be laid off. As a result, the family's economic condition is falling apart.

\subsection{The Impact of COVID-19 on the Economy of the Lower Class Communities in Rural Areas}

As illustrated in Table 1, the respondents experienced economic instability. More than half of the respondents agreed that this outbreak had led the family's economic condition into crisis. Some of them were experienced wage cuts to the laid-off of family members. The main factors causing this disruption are because the economic activity gradually deteriorated. Meanwhile, some other respondents said the economy was running well. This condition occurs in permanent employees of government agencies or on large-scale companies. An employee who works in such an environment does not experience a decline in economic conditions. It is different from workers in other sectors whose economy is on the verge of collapse.

Table 1. The economic impacts on the lower class communities in the rural area

\begin{tabular}{|l|c|c|}
\hline \multicolumn{1}{|c|}{ The Economic Impacts due to COVID-19 on Households } & Frequency & Percentage (\%) \\
\hline Financially unstable & 182 & 66.42 \\
\hline Financially stable & 92 & 33.58 \\
\hline Total & $\mathbf{2 7 4}$ & $\mathbf{1 0 0}$ \\
\hline
\end{tabular}

Previous studies state two economic impacts from disasters: direct and indirect impacts (Carrera et al., 2015). The direct impact might be an area or a country that directly undergoes economic instability. Many people experience occupation shocks, i.e., losing their jobs in the end, which becomes an economic burden for the country. The aftermath recovery, which requires significant funds, also worsens this condition. Further, the disaster also has an indirect impact. This relates to other sectors, such as a country's social politics.

Similar to the COVID-19 outbreak experienced by Indonesia, this pandemic had direct and indirect impacts. Economically, COVID-19 has brought economic depression to the country. It can be seen that tourism, which has become the main source of Indonesia's economy, is now forced to shut down to prevent wider disease transmission. Moreover, in 2020, Indonesia has been preparing premium tourism in various tourist attractions. This certainly makes Indonesia lose its assets and economic opportunities.

The disaster occurrence exposes the inequality of low-income societies because they have no social, political, and economic power (Motesharrei et al., 2014). The poor are getting worse because of the disaster. If this is not covered by social assistance, this vulnerability will make poor households increasingly less likely to rise from disaster. On the other hand, even though the disaster destroys the economy of the whole community, social inequality will be more open 
when there is a disaster. The poor who do not have assets and capital is getting worse, especially for workers who only rely on income from one job.

Table 2. The economic losses of the rural poor amidst the COVID-19 pandemic

\begin{tabular}{|l|c|c|}
\hline \multicolumn{1}{|c|}{ Options } & Frequency & Percentage (\%) \\
\hline Reduced income & 118 & 43.07 \\
\hline Jobs termination & 151 & 55.11 \\
\hline Arguing/fighting with a partner more often & 5 & 1.82 \\
\hline Total & $\mathbf{2 7 4}$ & $\mathbf{1 0 0}$ \\
\hline
\end{tabular}

As explained in Table 2, the economy of the lower classes was really at stake during the COVID-19 pandemic. Lower-class people feel the social and economic impact that is so strong. Many of them said that their income was reduced. In the trade sector, many traders complained about the decline in turnover. Moreover, the government closed traditional markets, so traders complained about the lack of income.

In addition, factory workers in Indonesia endure status uncertainties in their work. Many of them were laid off without receiving any compensation. Even when forced to take a temporary "off" from their work, the company chooses not to pay them because production activities have been stopped. The workers faced an economic downturn during that condition, specifically with married and having children. Workers do not have any earnings, but on the other side, life still goes on.

Besides the production workers, people who work in the hospitality and tourism sectors are going through the same impact. Due to social restrictions, numerous hoteliers undertake hotel closure. As a result, hotel workers were laid off without a salary. The situation impacts the workers and both parties, workers, and employees. They both are in the same detrimental circumstances. Workers at tourist sites also suffer. Most of the tourist objects in Indonesia are imposed closure, which makes workers do not receive their income.

Based on a study by Villanueva (2011), climate change is a disaster close to lower class society, which causes uncertainty and vulnerability. Usually, natural disasters in Indonesia are related to nature, such as a dreadful weather causing the agriculture sector to suffer a decline in income. But during the COVID-19 pandemic, the vulnerability of the lower class communities might lead to economic uncertainty. The futures of the worker who undergo a temporary layoff are hanged into precariousness. They are facing the uncertainty of the exact time to be back to work. The lower-class society is anxious about jobs termination. Besides being vulnerable to layoffs, they also have to apply for another job if they are forced to accept unpaid leave or unilateral dismissal.

Achievement of development is also inseparable from the economic activities of women. Previous studies state that disasters undermine development achievement plans, especially in developing countries where vulnerable groups are gripped by the poverty trap on postdisasters (Yokomatsu et al., 2014). In this study, the lower-class women also encounter a tremendous impact due to the COVID-19 pandemic. Women also have been enduring several obstacles due to the Work From Home policy. 


\subsection{The Work From Home Policy on the Rural Poor and Women}

The government adopts a policy of work-from-home for workers in Indonesia. This policy does not necessarily make the community feel easy at work. Various jobs cannot be done at home, so some companies close their companies. This makes people lose their jobs so that the poor are more vulnerable.

Although the policy of working from home is considered a solution for preventing outbreaks, most Indonesian people who are the lower middle class feel bad. The rules of working from home applied by the government cannot be made well by the community. This policy certainly benefits the upper class because work done at the office can be done at home using internet access. At the same time, the work of the lower classes cannot be done by working from home, so they cannot comply with the government's call. Some types of work such as street vendors, factory workers, self-service workers, online motorcycle taxi drivers, and freight couriers are lower-class jobs that cannot be done at home. The lower classes are the most vulnerable citizens exposed to COVID-19 risk.

Poverty in Indonesia is a big challenge for the country and its citizens. McMahon (2007) states that poverty is an obstacle for the country to rise after the disaster because the money used to carry out development is delayed to assist affected people, especially the poor. In handling COVID-19, the Indonesian government spent a very large budget. This budget is used for health facilities and vulnerable citizens. This pandemic has paralyzed various economic sectors, so poor people's existence is a big concern for the government.

Previous studies suggest that poor people build homes in unsafe areas, in addition to making them more vulnerable, adding to or creating other problems in long-term disaster planning, evacuation, and risk studies (Ferdinand et al., 2012). In health-related disasters, the poor are accused of producing unorganized city landscapes due to urbanization (Rashid et al., 2013). Regarding the risk of being exposed to COVID-19, some poor residents occupy inadequate housing. The poor living in slums are a big concern because slums are attached to a high risk of spreading disease. In addition, residents who live in slums do not have an awareness of the importance of maintaining health and hygiene, so poverty is easily linked to conditions that aggravate disasters. Previous study state that the idea of vulnerability strongly links poverty with the causes of disasters (Akter \& Mallick, 2013). The poor are vulnerable people in the event of a disaster.

Dunford \& Li (2011) explains that poverty is closely related to a vulnerability in poor communities for several reasons, including the place where they live, their living conditions, child neglect due to parental migration, and dependence on natural resources. Previous studies mention that the tsunami that struck Asia in 2008 caused the marine sector to be inaccessible, even though coastal populations depended on natural resources (Gaillard et al., 2008). Meanwhile, the vulnerability experienced by the poor in Indonesia is a complex matter. Such conditions make it difficult for the poor to deal with disasters and restore their lives. De Silva \& Kawasaki (2018) states that poverty in the face of disasters is very difficult to meet needs, and some are dependent on nature.

In addition to being directly affected by natural disasters, poor people also find the longterm effects of their work, commonly known as the "poverty trap", that the recovery situation will not occur without external assistance (Carter et al., 2007). In the face of the COVID-19 pandemic, the lower classes in Indonesia do not have any power to depend on external assistance from the government or donors. The assistance provided is very beneficial for lowerclass citizens because, without assistance, they cannot ensure their lives will go well.

Copyright (C 2021. Owned by Author(s), published by Society. This is an open-access article under the CC-BY-NC-SA license. https://doi.org/10.33019/society.v9i2.285 
If the upper-class people still have access to capital in banks, another case is with the lower class people who do not have health insurance to secure formal financial institutions. The poor also do not have access to formal credit (Parvin \& Shaw, 2013). In a pandemic like this, the lower classes are often trapped in poverty traps. This trap is a moneylender who is a source of loans for the poor. The existence of moneylenders has long been considered not a solution for the poor to get out of economic difficulties but instead to strangle them with a high-interest system. In conditions of difficulty, there is no other choice for lower-class citizens to survive. Even though the lower class citizens get help from the government, the existence of loan sharks is common in the community, so that the lower class citizens are not easy to get out of the circle.

Mallick et al. (2011) explain that low-income groups in Bangladesh do not receive enough disaster relief because they feel ashamed to be in the queue. Eventually, they sell their property or take credit from other sources. Other studies suggest that housing assistance programs experience other problems such as cultural and climate mismatches, poor locations, social problems, and lack of organizational capacity (Johnson, 2007). In contrast to Indonesia, residents who do not receive social assistance are above the poverty line but have a life that shifts below the poverty line. Residents like this are middle-class people who have never received social assistance and are not registered as beneficiaries. This condition turned out to be a problem in Indonesia because residents of this class at the time of the COVID-19 pandemic experienced a shift in position. Eventually, the number of the lower classes increased, but social assistance did not reach these layers.

Table 3. Impacts of the work from home policy for the women rural poor

\begin{tabular}{|l|c|c|}
\hline \multicolumn{1}{|c|}{ Options } & Frequency & Percentage (\%) \\
\hline Women receive more benefits & 46 & 16.62 \\
\hline $\begin{array}{l}\text { Women are disadvantaged because of the heavier } \\
\text { household chores }\end{array}$ & 114 & 41.69 \\
\hline $\begin{array}{l}\text { Women should have participated both in public } \\
\text { and domestic sectors }\end{array}$ & 109 & 39.84 \\
\hline $\begin{array}{l}\text { The husband has become more grumpy recently } \\
\text { (abusive relationship) }\end{array}$ & 5 & 1.85 \\
\hline Total & $\mathbf{2 7 4}$ & $\mathbf{1 0 0}$ \\
\hline
\end{tabular}

From Table 3, it can be seen that the COVID-19 pandemic and work-at-home policies pose problems for women. The workload of women is proven to increase during the COVID-19 pandemic. It means women are required to undertake both domestic and public responsibilities simultaneously. While working at home, women are preoccupied to balance these two things, first, their duty as a worker, and then, a mother who assists the household.

In patriarchal family culture, married women continue to perform gender segregation and signification as housewives who oblige to effectuate most domestic responsibilities (including household chores and caregiving) (Kan, 2008). As a result, women are "shouldering" the double burden of work and family tasks. A double burden can be defined as a situation where women have a greater workload than men. The division of labor at home by gender requires women to do the bulk of unpaid care work in the domestic sphere while men are not taking on greater responsibility for domestic work and unpaid care at the same rate. Previously, several studies in 
agrarian society, where patriarchal culture is strongly maintained, describe that domestic responsibilities intensity associated with unpaid care work represents a major barrier to women's equal participation in the formal workforce. Moreover, women continue to experience male domination in domestic spheres (households) (Debnath, 2015).

According to (Väänänen et al., 2004) study finds that women spend more than 10 hours working hours than men's work. In the study, it is stated that although the working hours of women and men in the public sector were the same, women's work was twice as long due to the double burden of domestic and public roles held at once. This shows that the workload of women is far greater than men because they have to perform multiple roles, especially women who live in such a subordinate environment. Women endure the double burden of being a housewife.

The dominance of men in the family makes women have greater responsibilities for housework and caregiving duties. Previous studies have shown that domestic work is classified as part of women's responsibility in a very high and unpaid workload (Sankaran, 2013). This homemaker role is considered unpaid because it is assumed as a household task. Natalier (2003) suggests that gender emerges as a holistic practice and identity in the household. Women will always be inflicted by numerous housework as long as husbands and wives do not negotiate gender practices and identity.

Although domestic work is closely related to women as wives who undergo a double burden, research in Japan revealed that husbands who took the household responsibilities were inadequate and not completed properly. Ueda (2005) reveals that even though husbands participate to take initiative in domestic work, it is still considered inadequate. Besides, women tend to perform household and caregiving duties because of distrust issues on their husbands regarding doing domestic work. The same similar cases have happened mainly on all women due to the accustomed habits to the patriarchal education that is already attached. In the theory of equity, women are responsible for all housework duties by the wife because the doctrine states that the husband plays a role as a breadwinner and holds authority over the wife or woman, especially if the wife is not participating in the labor market (Carriero \& Todesco, 2017).

On the other hand, although men also take the initiative to do house chores, still, women continue to perform most of the housework, childcare, and community obligations (Kan et al., 2011). The study further highlights the imbalance impact between roles as a husband and wife in the working women and house-husbands family. Even though men desire to perform domestic work in patriarchal families, they still think that wives must behave and be obedient to their husbands. Álvarez \& Miles (2006) found that when women participated in the labor market and reduced domestic work, men decided to decrease their time for domestic work.

The men's exclusion on the domestic sphere is inseparable from the social and cultural system in a patriarchal context. Women are being subordinated and exploited to undergo all the domestic work. It depicts the manifestation and institutionalization of male dominance and extension over women in society pursuing domestic harmony (Veltman, 2004). The majority of the families believe that the harmony of a family depends on women's behavior.

However, even though women get a chance to replace the dogma, in reality, patriarchal culture still lasts. According to a study conducted by Luke et al. (2014), working women tend to have an opportunity to restore patriarchal cultures and norms in the family. Household chores can be easily negotiated, specifically when the wife's salary exceeds the husband's income. 
Previous studies have shown that women's dependence on husbands causes gender disparities in the domestic sphere (Sullivan \& Gershuny 2013).

A study by Noonan et al. (2007) explores the equality of domestic workloads in dual careers households can be pursued by fairly managing the division of labor for both wife and husband, which can be adjusted based on their timeline. On the contrary, when women and men have the same work-time duration, every household responsibility becomes the women's obligation.

As a developing country located in the ring of fire, Indonesia has been known as a disasterprone country. Altogether with countries all over Southeast Asia and the Pacific, Indonesia has experienced various disasters and received severe impacts for years. Based on Nhu et al. (2011), Vietnam's geographical location is a developing country with a disaster-prone area. From this fact, it can be implied that the country is vulnerable to poverty during the emergence of disasters. Poverty is believed to be a serious barrier to achieving socio-economic development amidst disaster emersion. This is similar in Indonesia, where disaster mitigation requires great effort to redevelop the problems.

In 2020, Indonesia was preparing a strategy for economic progress. Many sectors of the Indonesian economy were massively built. Various tourism sectors are being boosted on a small and large scale. The government in 2020 also prepares premium tourism and international events. On the other side, developed by society, local tourism has become Indonesia's highlight for promoting world tourism. Tourist objects managed by the locals have proven to contain a very good influence on the area. It is not only targeted as branding for the country. However, local tourism has become an economic magnet for society who lives in the area. But, due to COVID-19 emersion, this sector significantly deteriorated. The closure of tourism sites has a quite serious impact. Traders who sell at tourism sites end up suffering huge losses.

\subsection{Government social assistance for women in the rural area who affected by the COVID-19 pandemic}

The World Bank proposed the concept of "poverty vulnerability" in 2000, referring to several things such as poor harvests, unemployment, serious illness, or severe natural disasters (Xu et al., 2017). In line with Sawada \& Takasaki (2017), poor people are very vulnerable to natural disasters, and it is a major barrier to reducing poverty and facilitating economic development. This is a complicated paradox when the state tries to overcome poverty, but at the same time, the poor are seen as a barrier to poverty alleviation. The state budget originally intended for developing other sectors is used for poverty alleviation through social assistance. As noted in Table 4, the social assistance provided by the Indonesian government reaps different responses from various groups.

Table 4. The government's social assistance for the rural poor amid the COVID-19 pandemic

\begin{tabular}{|l|c|c|}
\hline \multicolumn{1}{|c|}{ Options } & Frequency & Percentage (\%) \\
\hline Preserve the vulnerable households & 118 & 42.95 \\
\hline It's supposed to be the government's responsibility & 81 & 29.51 \\
\hline Mistargeted distribution & 75 & 27.54 \\
\hline Total & $\mathbf{2 7 4}$ & $\mathbf{1 0 0}$ \\
\hline
\end{tabular}

Copyright (C) 2021. Owned by Author(s), published by Society. This is an open-access article under the CC-BY-NC-SA license. 
In Table 4, it can be seen that the social assistance issued by the government to handle COVID-19 gains various responses. So far, the government has provided various types of assistance, whether in conditional cash transfer, credit relief programs, basic electricity tariffs to staple food disbursement. However, unfortunately, these aids only cover a few community sections.

Social assistance for the lower-class communities is needed for poverty alleviation and intended to protect them. If the lower classes do not get any assistance, their lives will worsen. On the other side, this issue is a part of the state's responsibility for the people. But still, the social aid provided gained various responses, stating that the social assistance distribution might not be on target. The existence of social inequality in Indonesia makes social assistance a sensitive issue for Indonesians. The social assistance provided is not through strict recipient selection procedures, which causes social jealousy.

In addition, social assistance for the lower class has been experiencing several issues due to unspecified fluctuation of criteria and the middle-class on poverty indicators. The catastrophe influences this case, transforming the middle-class into the lower class so that it impacts the growth of the poor.

According to Onuoha (2009), in Nigeria, a disaster occurred such a pipe blasting associated as a result of poverty due to the greed of the poor. This shows that poverty is seen as a negative form that aggravates the occurrence of disasters. Similarly, poverty has been seen as an obstacle to natural disaster management in Indonesia, including COVID-19. After the rapid pandemic emerged, the Indonesian government provided social assistance to the society. Also, the government urges the lower class to get used to healthy habits to reduce the spread of infections. In this case, poverty is the epicenter of the opposite to accelerate the epidemic.

On the other hand, the upper-class is not the only one vulnerable to the virus. In contrast, it evokes a tremendous impact in all socio-economic classes. The education, service, manufacturing, and trading sectors are falling down. However, the fast food and shipping industries have shown rapid growth. Various occupational professions experience the same situation.

Davies et al. (2009) reveal that the lower-class is the most vulnerable to the disaster because of their incapability to cope with related impacts due to the low adaptability. The COVID-19 impact is a substantial challenge for the middle-lower class society. The lower class is classified as a vulnerable society concerning poverty. They could be more helpless if any shock events tortured them. Apart from being unable to access capital, the lower classes also lack bargaining positions and social, economic, and political security.

In line with Winsemius et al. (2018), the poor's vulnerability is caused by the low access to savings, loans, and social protection. The poor will never have access to banks to borrow capital because they do not have assets that can be used as collateral. In addition, they have not enough savings or even none at all. During the COVID-19 pandemic, there is nothing that the lowerclass society can rely on, then expecting the government's social assistance. On the other hand, the private sector does not participate in disaster risk mitigation, including the poor. It strategically cuts its market. Then, safety nets that are financed by the public cannot be accessed by the poor due to the absence of markets (Christopher et al., 2001).

The lower-class society working as a farmer and laborer can keep on living by implementing survival strategies by relying on work-based as own ownership. A different case happens to the poor who work as laid-off laborers. This situation brings economic shocks to households and difficulties getting capital and loans. 
Studies conducted in Vietnam show that rural households in Vietnam are five times poorer than urban residents. In contrast, poverty in rural areas decreases more slowly, making it difficult to recover from disasters, and there is no investment in rural infrastructure (Lohmann \& Lechtenfeld, 2015). This is also the case in Indonesia, where the rural poor do not have sufficient access to recover from disasters.

Society who experienced the changes during this pandemic concluded that all parts and classes undergo socio-economic downturns. The fall of the national economy is caused by the discontinuation of products from companies across Indonesia and job terminations on a large scale. On the other side, the lower classes encounter an unusual economic struggle. However, there is nothing to be finished because of the lack of access to good adaptation.

\section{Conclusion}

The enormous impacts of the COVID-19 outbreak had been affected all levels of society. For the lower classes, this pandemic brings an unstable economy. Due to the circumstances, the poor communities experience economic shock and welfare instability. Although most societies have a better understanding of healthy lifestyle and digital transformation, the poor have little opportunity to achieve these things.

The lack of access and knowledge makes the poor vulnerable and worsens because of this outbreak. On the other hand, not all lower-class people are fully covered by social assistance even though they struggle with an economic downturn. Some receive job termination letters, while others work amid the threat of a COVID-19 pandemic. Additionally, women encounter various forms of injustice and bear a double burden in the aftermath of the Work from Home policy due to men's lack of awareness of justice and gender equality.

\section{Acknowledgment}

The authors are grateful to express gratitude to those who have had the pleasure to cooperate during this research.

\section{Declaration of Conflicting Interests}

The authors have declared no potential conflicts of interest concerning the study, authorship, and/or publication of this article.

\section{References}

Adeagbo, A., Daramola, A., Carim-Sanni, A., Akujobi, C., \& Ukpong, C. (2016). Effects of natural disasters on social and economic well being: A study in Nigeria. International Journal of Disaster Risk Reduction, 17, 1-12. https:/ / doi.org/10.1016/j.ijdrr.2016.03.006

Ahmed, F., Ahmed, N., Pissarides, C., \& Stiglitz, J. (2020). Why inequality could spread COVID19. The Lancet Public Health, 5(5), e240. https:/ / doi.org/10.1016/s2468-2667(20)30085-2

Akter, S., \& Mallick, B. (2013). The poverty-vulnerability-resilience nexus: Evidence from Bangladesh. Ecological Economics, 96, 114-124. https:/ / doi.org/10.1016/j.ecolecon.2013.10.008

Alon, T., Doepke, M., Olmstead-Rumsey, J., \& Tertilt, M. (2020). The Impact of COVID-19 on Gender Equality. Journal of Chemical Information and Modeling. https:/ / doi.org/10.3386/w26947 
The Impact of the COVID-19 Pandemic and Work From Home Policy on Poor Communities and Women in Rural Area

Álvarez, B., \& Miles, D. (2006). Husbands' housework time: Does wives' paid employment make a difference? Investigaciones Economicas, $x x x(1), 5-31$. Retrieved from https:/ / www.redalyc.org/pdf/173/17330101.pdf

Alvarez, F., Argente, D., \& Lippi, F. (2020). A Simple Planning Problem for COVID-19 Lockdown. SSRN Electronic Journal. https:/ / doi.org/10.2139/ssrn.3569911

Anser, M. K., Yousaf, Z., Khan, M. A., Nassani, A. A., Alotaibi, S. M., Qazi Abro, M. M., . . Zaman, K. (2020). Does communicable diseases (including COVID-19) may increase global poverty risk? A cloud on the horizon. Environmental Research, 187, 109668. https:/ / doi.org/10.1016/j.envres.2020.109668

Atkeson, A. G. (2020). What will be the economic impact of COVID-19 in the US? Rough estimates of disease scenarios. Research Department Staff Reports (Federal Reserve Bank of Minneapolis).

Baker, S., Bloom, N., Davis, S., \& Terry, S. (2020). Covid-induced economic uncertainty. National Bureau of Economic Research. https:/ / doi.org/10.3386/w26983

Baldwin, R., \& Mauro, B. W. di. (2020). Economics in the time of COVID-19. In Economics in the Time of COVID-19.

Buheji, M., da Costa Cunha, K., Beka, G., Mavrić, B., Leandro do Carmo de Souza, Y., Souza da Costa Silva, S., Hanafi, M., \& Chetia Yein, T. (2020). The extent of COVID-19 pandemic socio-economic impact on global poverty. A global integrative multidisciplinary review. American Journal of Economics. https:// doi.org/10.5923/j.economics.20201004.02

Carrera, L., Standardi, G., Bosello, F., \& Mysiak, J. (2015). Assessing direct and indirect economic impacts of a flood event through the integration of spatial and computable general equilibrium modelling. Environmental Modelling and Software. https:/ / doi.org/10.1016/j.envsoft.2014.09.016

Carriero, R., \& Todesco, L. (2017). The interplay between equity and gender ideology in perceived housework fairness: Evidence from an experimental vignette design. Sociological Inquiry. https:// doi.org/10.1111/soin.12162

Carter, M. R., Little, P. D., Mogues, T., \& Negatu, W. (2007). Poverty Traps and natural disasters in Ethiopia Honduras. World Development. https:/ / doi.org/10.1016/j.worlddev.2006.09.010

Cavallo, E., Galiani, S., Noy, I., \& Pantano, J. (2013). Catastrophic natural disasters and economic growth. Review of Economics and Statistics. https://doi.org/10.1162/REST_a_00413

Christopher, I., Liljelund, A., \& Mitchell, J. (2001). Re-framing risk: The changing context of disaster mitigation and preparedness. Disasters. https://doi.org/10.1111/14677717.00171

Coibion, O., Gorodnichenko, Y., \& Weber, M. (2020). Labor markets during the COVID-19 crisis: A preliminary view. SSRN Electronic Journal. https://doi.org/10.2139/ssrn.3574736

Davies, M., Oswald, K., \& Mitchell, T. (2009). Climate change adaptation , disaster risk reduction and social protection. Change.

De Silva, M. M. G. T., \& Kawasaki, A. (2018). Socioeconomic vulnerability to disaster risk: A case study of flood and drought impact in a rural Sri Lankan community. Ecological Economics. https:/ / doi.org/10.1016/j.ecolecon.2018.05.010

Debnath, S. (2015). The impact of household structure on female autonomy in developing countries. Journal of Development Studies. https:/ / doi.org/10.1080/00220388.2014.983909

Dunford, M., \& Li, L. (2011). Earthquake reconstruction in Wenchuan: Assessing the state

Copyright (C 2021. Owned by Author(s), published by Society. This is an open-access article under the CC-BY-NC-SA license. 
The Impact of the COVID-19 Pandemic and Work From Home Policy on Poor Communities and Women in Rural Area

overall plan and addressing the "forgotten phase." Applied Geography. https:/ / doi.org/10.1016/j.apgeog.2011.01.001

Ferdinand, I., O'Brien, G., O'Keefe, P., \& Jayawickrama, J. (2012). The double bind of poverty and community disaster risk reduction: A case study from the Caribbean. International Journal of Disaster Risk Reduction. https:/ / doi.org/10.1016/j.ijdrr.2012.09.003

Fernandes, N. (2020). Economic effects of coronavirus outbreak (COVID-19) on the world economy. SSRN Electronic Journal. https:/ / doi.org/10.2139/ssrn.3557504

Fothergill, A. (2003). The stigma of charity: Gender, class, and disaster assistance. Sociological Quarterly. https:// doi.org/10.1111/j.1533-8525.2003.tb00530.x

Fuchs-Schelnund, N. (2020). Gender structure of paper submissions at the Review of Economic Studies during COVID-19: First evidence. Retrieved from https://www.wiwi.unifrankfurt.de/profs/fuchs/staff/fuchs/paper/FemaleSubmissionsCovid19.pdf

Gaillard, J. C., Clavé, E., \& Kelman, I. (2008). Wave of peace? Tsunami disaster diplomacy in Aceh, Indonesia. Geoforum. https://doi.org/10.1016/j.geoforum.2007.10.010

Guerrieri, V., Lorenzoni, G., Straub, L., \& Werning, I. (2020). Macroeconomic implications of COVID-19: Can negative supply shocks cause demand shortages? SSRN Electronic Journal. https:/ / doi.org/10.2139/ssrn.3570096

Hall, R. E., Jones, C. I., \& Kleneow, P. J. (2020). Trading off consumption and COVID-19 deaths. Quarterly Review. https:/ / doi.org/10.21034/qr.4211

Hevia, C., \& Neumeyer, A. (2020). A conceptual framework for analyzing the economic impact of COVID-19 and its policy implications. COVID19 Policy Document Series.

Inoue, H., \& Todo, Y. (2020). The propagation of the economic impact through supply chains: The case of a mega-city lockdown against the spread of COVID-19. In arXiv. https:/ / doi.org/10.2139/ssrn.3564898

Johnson, C. (2007). Strategic planning for post-disaster temporary housing. Disasters. https:/ / doi.org/10.1111/j.1467-7717.2007.01018.x

Kan, M. Y. (2008). Does gender trump money? Housework hours of husbands and wives in Britain. Work, Employment and Society. https:// doi.org/10.1177/0950017007087416

Kan, M. Y., Sullivan, O., \& Gershuny, J. (2011). Gender convergence in domestic work: Discerning the effects of interactional and institutional barriers from large-scale data. Sociology. https:/ / doi.org/10.1177/0038038510394014

Kreimer, A., Arnold, M., Carlin, A., \& World Bank, the (WB). (2003). Building safer cities, the future of disaster risk. In Disaster Risk Management Series.

Loayza, N., \& Pennings, S. M. (2020). Macroeconomic policy in the time of COVID-19: A primer for developing countries. World Bank Research and Policy Briefs.

Lohmann, S., \& Lechtenfeld, T. (2015). The effect of drought on health outcomes and health expenditures in rural Vietnam. World Development. https:/ / doi.org/10.1016/j.worlddev.2015.03.003

Luke, N., Xu, H., \& Thampi, B. V. (2014). Husbands' participation in housework and child care in India. Journal of Marriage and Family. https:/ / doi.org/10.1111/jomf.12108

Mallick, B., Rubayet Rahaman, K., \& Vogt, J. (2011). Social vulnerability analysis for sustainable disaster mitigation planning in coastal Bangladesh. Disaster Prevention and Management: An International Journal. https:/ / doi.org/10.1108/09653561111141682

Mamun, M. A., \& Ullah, I. (2020). COVID-19 suicides in Pakistan, dying off not COVID-19 fear but poverty? - The forthcoming economic challenges for a developing country. In Brain, Behavior, and Immunity. https:/ / doi.org/10.1016/j.bbi.2020.05.028 
The Impact of the COVID-19 Pandemic and Work From Home Policy on Poor Communities and Women in Rural Area

McKibbin, W., \& Roshen, F. (2020). The global macroeconomic impacts of COVID-19. In Brookings Institute.

McMahon, M. M. (2007). Disasters and poverty. In Disaster Management and Response. https:/ / doi.org/10.1016/j.dmr.2007.09.001

Motesharrei, S., Rivas, J., \& Kalnay, E. (2014). Human and nature dynamics (HANDY): Modeling inequality and use of resources in the collapse or sustainability of societies. Ecological Economics, 101, 90-102. https:/ / doi.org/10.1016/j.ecolecon.2014.02.014

Natalier, K. (2003). "I'm not his wife": Doing gender and doing housework in the absence of women. Journal of Sociology. https:/ / doi.org/10.1177/00048690030393003

Nhu, O.L., Thuy, N.T.T., Wilderspin, I., \& Coulier, M. (2011). A preliminary analysis of flood and storm disaster data in VietNam. Global Assessment Report on Disaster Risk Reduction.

Nicola, M., Alsafi, Z., Sohrabi, C., Kerwan, A., Al-Jabir, A., Iosifidis, C., Agha, M., \& Agha, R. (2020). The socio-economic implications of the coronavirus pandemic (COVID-19): A review. In International Journal of Surgery. https:/ / doi.org/10.1016/j.ijsu.2020.04.018

Noonan, M. C., Estes, S. B., \& Glass, J. L. (2007). Do workplace flexibility policies influence time spent in domestic labor? Journal of Family Issues. https:// doi.org/10.1177/0192513X06292703

Onuoha, F. C. (2009). Why the poor pay with their lives: Oil pipeline vandalisation, fires and human security in Nigeria. Disasters. https:/ / doi.org/10.1111/j.1467-7717.2008.01079.x

Ozili, P. K., \& Arun, T. (2020). Spillover of COVID-19: Impact on the global economy. SSRN Electronic Journal. https://doi.org/10.2139/ssrn.3562570

Parvin, G. A., \& Shaw, R. (2013). Microfinance institutions and a coastal community's disaster risk reduction, response, and recovery process: A case study of Hatiya, Bangladesh. Disasters. https:/ / doi.org/10.1111/j.1467-7717.2012.01292.x

Rashid, S. F., Gani, S., \& Sarker, M. (2013). Urban Poverty, Climate Change and Health Risks for Slum Dwellers in Bangladesh. https:/ / doi.org/10.1007/978-4-431-54249-0_4

Sankaran, K. (2013). Domestic work, unpaid work and wage rates. In Economic and Political Weekly.

Sawada, Y., \& Takasaki, Y. (2017). Natural disaster, poverty, and development: An introduction. World Development. https:// doi.org/10.1016/j.worlddev.2016.12.035

Sułkowski, Ł. (2020). COVID-19 pandemic; recession, virtual revolution leading to deglobalization? Journal of Intercultural Management. https://doi.org/10.2478/joim-20200029

Sullivan, O., \& Gershuny, J. (2013). Domestic outsourcing and multitasking: How much do they really contribute? Social Science Research. https:/ / doi.org/10.1016/j.ssresearch.2013.05.004

Sumner, A., Hoy, C., \& Ortiz-Juarez, E. (2020). Estimates of the impact of COVID-19 on global poverty. UNU WIDER Working Paper 2020/43.

Tesso, G. (2020). The economics of COVID-19: Economic Growth, unemployment and the challenge to progress out of poverty in Ethiopia. Retrieved from academia.edu.

Toda, A. A. (2020). Susceptible-Infected-Recovered (SIR) dynamics of COVID-19 and economic impact. In arXiv.

Toya, H., \& Skidmore, M. (2007). Economic development and the impacts of natural disasters. Economics Letters. https:// doi.org/10.1016/j.econlet.2006.06.020

Ueda, A. (2005). Intrafamily time allocation of housework: Evidence from Japan. Journal of the Japanese and International Economies. https:/ / doi.org/10.1016/j.jjie.2003.12.002

Copyright (C) 2021. Owned by Author(s), published by Society. This is an open-access article under the CC-BY-NC-SA license.

https://doi.org/10.33019/society.v9i2.285

536 
The Impact of the COVID-19 Pandemic and Work From Home Policy on Poor Communities and Women in Rural Area

Väänänen, A., Kevin, M. V., Ala-Mursula, L., Pentti, J., Kivimäki, M., \& Vahtera, J. (2004). The double burden of and negative spillover between paid and domestic work: Associations with health among men and women. Women and Health. https://doi.org/10.1300/J013v40n03_01

Van Lancker, W., \& Parolin, Z. (2020). COVID-19, school closures, and child poverty: a social crisis in the making. In The Lancet Public Health. https://doi.org/10.1016/S24682667(20)30084-0

Veltman, A. (2004). The Sisyphean Torture of housework: Simone de Beauvoir and inequitable divisions of domestic work in marriage. Hypatia: A Journal of Feminist Philosophy. https:// doi.org/10.2979/hyp.2004.19.3.121

Villanueva, P. S. (2011). Learning to ADAPT: Monitoring and evaluation approaches in climate change adaptation and disaster risk reduction - challenges, gaps and ways forward. SCR Discussion Paper 9.

Wenham, C., Smith, J., \& Morgan, R. (2020). COVID-19: the gendered impacts of the outbreak. In The Lancet. https:/ / doi.org/10.1016/S0140-6736(20)30526-2

Winsemius, H. C., Jongman, B., Veldkamp, T. I. E., Hallegatte, S., Bangalore, M., \& Ward, P. J. (2018). Disaster risk, climate change, and poverty: Assessing the global exposure of poor people to floods and droughts. Environment and Development Economics. https:/ / doi.org/10.1017/S1355770X17000444

Wright, A. L., Sonin, K., Driscoll, J., \& Wilson, J. (2020). Poverty and economic dislocation reduce compliance with COVID-19 shelter-in-place protocols. Journal of Economic Behavior and Organization. https:/ / doi.org/10.1016/j.jebo.2020.10.008

Xu, D., Peng, L., Liu, S., Su, C., Wang, X., \& Chen, T. (2017). Influences of migrant work income on the poverty vulnerability disaster threatened area: A case study of the Three Gorges Reservoir area, China. International Journal of Disaster Risk Reduction. https:/ / doi.org/10.1016/j.ijdrr.2017.03.001

Yokomatsu, M., Wada, H., Ishiwata, H., Kono, T., \& Wakigawa, K. (2014). An economic growth model for disaster risk reduction in developing countries. 2014 IEEE International Conference on Systems, Man, and Cybernetics (SMC). https:// doi.org/10.1109/smc.2014.69741

\section{About the Authors}

1. Lutfi Apreliana Megasari is a graduate student of the Sociology undergraduate program, Universitas Airlangga, Indonesia. Her thesis was about agriculture and rural culture. She completed her study in 2019.

E-Mail: lutfiaprilmegasari@gmail.com

2. Siti Mas'udah obtained his Doctoral degree in Social Sciences from Universitas Airlangga, Indonesia, in 2020. The author is an Assistant Professor at the Department of Sociology, Faculty of Social and Political Sciences, Universitas Airlangga, Indonesia. She teaches several courses in the Department of Sociology: sociology of the family, sociology of gender, sociology of law, gender and human rights, sociology of deviant behavior, and the Indonesian socio-cultural system. She also serves as the journal's editor-in-chief of 
The Impact of the COVID-19 Pandemic and Work From Home Policy on Poor Communities and Women in Rural Area

Masyarakat, Kebudayaan dan Politik (Community, Culture and Politics) indexed by Emerging Source Citation Index (ESCI), Clarivate Analytics, Web of Science.

E-Mail: siti.masudah@fisip.unair.ac.id

3. Priyono Tri Febrianto obtained his Master's degree from Universitas Gadjah Mada, Indonesia, in 2004. The author is an Assistant Professor at the Department of Primary School Teacher Education, Faculty of Science Education, Universitas Trunojoyo Madura, Indonesia.

E-Mail: priyono.febrianto@trunojoyo.ac.id

Copyright (C) 2021. Owned by Author(s), published by Society. This is an open-access article under the CC-BY-NC-SA license. 